Stefanelli M, Wyatt J, eds. Artificial Intelligence in Medicine. Proceedings of the fifth Conference on Artificial Intelligence in Medicine-Europe, AIME 95. Pavia, Italy; June 25-28, 1995. Berlin, Germany: Springer-Verlag; 1995:165-172.

29. Pittet D, Wenzel RP. Nosocomial bloodstream infections: secular trends in rates, mortality, and contribution to total hospital deaths. Arch Intern Med 1995;155:1177-1184.

30. Boyce JM. Incidence of methicillin-resistant Staphylococcus aureus (MRSA) in hospitals in the United States. Infect Control Hosp Epidemiol 1995;16:19. Abstract.

31. Peacock JE, Marsik FJ, Wenzel RP. Methicillin-resistant Staphylococcus aureus: introduction and spread within a hospital. Ann Intern Med 1980;93:526-532.

32. Craven DE, Reed C, Kollisch N, et al. A large outbreak of infections caused by a strain of Staphylococcus aureus resistant to oxacillin and aminoglycosides. Am J Med 1981;71:53-58.

33. Mulligan ME, Murray-Leisure KA, Ribner BS, et al. Methicillinresistant Staphylococcus aureus: a consensus review of the microbiology, pathogenesis, and epidemiology with implications for prevention and management. Am J Med 1993;94:313328.

34. Reboli AC, John JF Jr, Platt CG, Cantey J. Methicillin-resistant Staphylococcus aureus outbreak at a Veterans' Affairs medical center: importance of carriage of the organism by hospital personnel. Infect Control Hosp Epidemiol 1990;11:291-296.

35. Cohen SH, Morita MM, Bradford M. A seven-year experience with methicillin-resistant Staphylococcus aureus. Am J Med 1991;91:233S-237S.

36. Jernigan JA, Titus MG, Gröschel DHM, Getchell-White SI, Farr BM. Effectiveness of contact isolation during a hospital outbreak of methicillin-resistant Staphylococcus aureus. Am J Epidemiol 1996;143:496-504.

37. Walsh TJ, Vlahov D, Hansen SL, et al. Prospective microbiologic surveillance in control of nosocomial methicillin-resistant Staphylococcus aureus. Infect Control 1987;8:7-14.

38. Rao N, Jacobs S, Joyce L. Cost effective eradication of an out- break of methicillin-resistant Staphylococcus aureus in a skilled nursing facility. Infect Control Hosp Epidemiol 1988;9:255-260.

39. Lugeon C, Blanc D, Wenger A, Francioli P. Molecular epidemiology of methicillin-resistant Staphylococcus aureus at a lowincidence hospital over a 4-year period. Infect Control Hosp Epidemiol 1995;16:260-267.

40. McDonald CJ, Hui SL, Smith DM, et al. Reminders to physicians from an introspective computer medical record. A two year randomized trial. Ann Intern Med 1984;100:130-138.

41. McDonald CJ, Tierney WM. Computer-stored medical records. Their future role in medical practice. JAMA 1988;259:34333440.

42. Tate KE, Gardner RM, Waever LK. A computerized laboratory alerting system. MD Computing 1990;7:296-301.

43. McDonald CJ, Tierney WM, Overhage JM, Martin DK, Wilson GA. The Regenstrief medical record system: 20 years of experience in hospitals, clinics and neighborhood health canters. MD Computing 1992;9:206-17.

44. Evans RS, Pestotnik SL, Classen DC, Burke JP. Development of an automated antibiotic consultant. MD Computing 1993;10:1722.

45. Rind DM, Safran C, Philips RS, et al. Effects of computer-based alerts on the treatment and outcomes of hospitalized patients. Arch Intern Med 1994;154:1511-1517.

46. Classen DC, Burke JP. The computer-based patient record: the role of the hospital epidemiologist. Infect Control Hosp Epidemiol 1995:729-736.

47. Hill RLR, Duckworth GL, Casewell MW. Elimination of nasal carriage of methicillin-resistant Staphylococcus aureus with mupirocin during a hospital outbreak. J Antimicrob Chemother 1988;22:377-384.

48. Weems JJ. A plea from the sole: let's keep the 'shoe leather' in healthcare epidemiology. Infect Control Hosp Epidemiol 1996;17:42-43.

\title{
Fourth Decennial Conference on Nosocomial Infections, Year 2000
}

\section{Gina Pugliese, RN, MS; Martin S. Favero, PhD Medical News Editors}

The CDC has sponsored three previous international conferences on the control of nosocomial infections, in 1970, 1980, and 1990. Plans currently are underway for the newest and largest of these conferences, to be held April 16-19, 2000, at the Marriott Marquis Hotel in Atlanta, Georgia. The Year 2000 conference is sponsored by the $\mathrm{CDC}$ and the
National Foundation for Infectious Diseases (NFID), and is cosponsored by the Association for Professionals in Infection Control and Epidemiology, Inc (APIC), and the Society for Healthcare Epidemiology of America, Inc (SHEA), in cooperation with the American Hospital Association (AHA). The Year 2000 conference will be held in conjunction with SHEA's 10th Annual Meeting in the year 2000 .

The Year 2000 Coordinating Committee, chaired by the director of the CDC's Hospital Infections Program, with representatives from NFID, APIC, SHEA, and AHA, met recently at the CDC in Atlanta to plan the conference. It is estimated that 2,000 individuals will attend. For the first time, there will be commercial exhibits at the conference. Registration, the opening session, and a reception are scheduled for Saturday, April 15, and plenary, concurrent, and poster sessions will be held through Wednesday, April 19, 2000. Publicity plans are being made. 